\title{
Optimization of the Chemical Oxygen Demand Removal from the Rural Domestic Wastewater using Taguchi Experimental Design Method
}

\author{
AHMED M. OSMAN KHAIRALLA ${ }^{1,2}$; LU XIWU $^{* 1}$ \\ ${ }^{1}$ Department of Environmental Science and Engineering, Southeast University, Nanjing 210096, \\ China. \\ ${ }^{2}$ Department of Civil Engineering, Karary University, Khartoum 12304, Sudan.
}

\begin{abstract}
KEYWORD: Taguchi method; orthogonal array design; ANOVA; Signal to noise ratio;
ABSTRACT: In the present study, two stages of upflow anaerobic filters (UAF) were applied and the performance efficiency of UAF reactor was evaluated for rural domestic wastewater treatment under different operational conditions such as temperature (T), hydraulic retention time (HRT), acidity $(\mathrm{pH})$ and different organic loading rates (OLR). In addition, the optimal chemical oxygen demand (COD) removal and operation factors were determine by using Taguchi experimental design method. $\mathrm{An}_{9}\left(3^{4}\right)$ orthogonal array was selected as the experimental plan for the four parameters mentioned above. The results demonstrated that all the factors had a significant influence on the COD removal efficiency. The obtained results allowed concluding that the optimal conditions in term of COD removal were initial $\mathrm{pH}$ of the wastewater of 7 , temperature of $25^{\circ} \mathrm{C}$, HRT of 1.5 day and OLR of $0.166 \mathrm{Kg}$. COD/m3.day. Moreover, the results showed that the HRT had highest percentage contribution in the COD removal process with $39.92 \%$, followed by temperature of $33.78 \%$, OLR of $13.75 \%$ and the $\mathrm{pH}$ of $9.18 \%$. Confirmatory experiments conducted at the optimized conditions and compared with the predicted result show a good agreement. At the end of the experimental study, the UAF reactor operated three months with real domestic wastewater and the obtained COD removal results at these optimum conditions was $56.5 \%$ with an average final COD concentration of $89.1 \mathrm{mg} / \mathrm{l}$.
\end{abstract}

\section{INTRODUCTION}

The Anaerobic reactor is one of the most important biological treatment processes used to convert organic matter into a biogas, a source of energy with minimal quantity of sludge ${ }^{[1]}$. High-rate anaerobic reactors such as UAF reactor is often applied as pretreatment of domestic wastewater to remove the organic and inorganic matter by the microorganisms in the absence of molecular oxygen. The UAF reactors have been widely used in developing countries for domestic and industrial wastewater treatment ${ }^{[2,3]}$ due to several advantages include a small space requirement, no need for aeration, low operation and maintenance costs, reduced of sludge bulking, production of biogas ${ }^{[4,5]}$.

In general, some of the performance factors have significant effects on the anaerobic decomposition of domestic wastewater such as temperature, $\mathrm{pH}, \mathrm{HRT}$, OLR, suspended solid, and reactor design ${ }^{[6]}$. Therefore, these factors and other must be taken under consideration when operated the anaerobic treatment process. In this research paper, the $\mathrm{L}_{9}\left(3^{4}\right)$ Taguchi orthogonal array (TOA) was applied, and the COD removal efficiency in an anaerobic reactor considered as the response function of the experiments. The Taguchi method was utilized to optimize the COD removal efficiency and to evaluate the important operation factors that have significant effects on the performance of the anaerobic treatment. 


\section{MATERIAL AND METHODS}

\section{Experimental Setup}

A laboratory scale of the two upflow anaerobic filters (UAFs) with the total working volume of 23.56 liters ( $1.5 \mathrm{~m}$ height, $0.1 \mathrm{~m}$ diameter each one) were applied to optimize the important operation factors that have effects on the COD removal process. The performance efficiency of the UAF reactors for COD removal from domestic wastewater was evaluated at different operation conditions according to Taguchi method. The UAF was filled with non- woven fabric media to improve the microorganism growth on the biofilm. These reactors were fed by activated sludge taken from the municipal sewage treatment plant in Wuxi city- China, and then the UAF reactors operated with $48 \mathrm{hrs}$ of HRT until the reactor reached the steady state after 28 days with the stability of the COD removal ratio.

Firstly, the synthetic domestic wastewater was used to optimize the COD removal process via UAF reactor and it prepared daily in the laboratory 100 liter plastic tank using glucose as the main organic source, ammonium chloride as the nitrogen source and the potassium phosphate as the phosphorus source. The influent COD concentrations varied between 125 to $500 \mathrm{mg} / \mathrm{l}$ during the entire experiments. The reactors were equipped with wastewater by using a peristaltic pump to control the flow rate and adjusted HRT for the reactors. During experimental operations, the influent $\mathrm{pH}$ was adjusted at desired values by adding $\mathrm{NaOH}$ or $\mathrm{H} 2 \mathrm{SO}$. In addition, the room temperature was adjusted and controlled by automatic thermostat lamps system. Secondly, after accomplished the optimization of the COD treatment process, the UAF reactor was ran continuously three months with real domestic wastewater to evaluate the reactor performance for long time operation. The raw domestic wastewater was taken from the main manhole in southeast university, Wuxi campus, as shown table 1 . In addition, the anaerobic reactor was operated in four phases at different operation conditions that considered in the previous of optimization study. The $\mathrm{pH}$ value was maintained in certain value $(\mathrm{pH}=7)$ during conducted experiments, and the temperature changed in three values 25 ${ }^{\circ} \mathrm{C}, 20{ }^{\circ} \mathrm{C}$ and $15^{\circ} \mathrm{C}$, respectively. In addition, different of HRTs included 36, 24, 18 and $12 \mathrm{hrs}$ were evaluated during the experimental operations. The schematic diagram of the anaerobic reactor is shown in Fig.1.

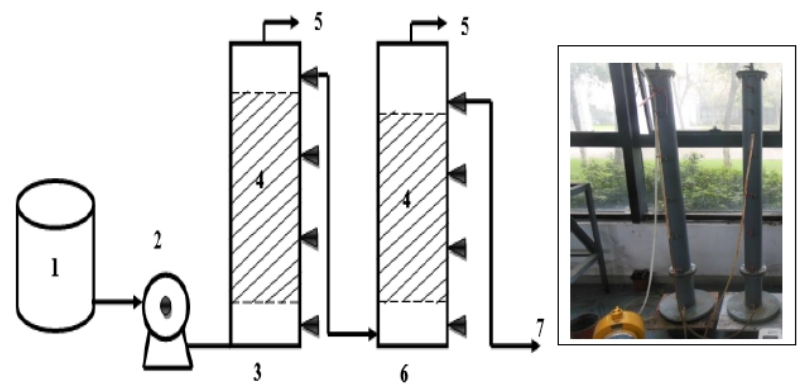

Fig. 1. Schematic diagram of the two phases of up flow anaerobic filter; 1. Influent tank; 2.peristaltic pump; 3. First anaerobic filter; 4. Non-woven fabric media; 5. Biogas production; 6. Second anaerobic filter; 7. Effluent wastewater.

Table 1 Chemical characterization of raw wastewater

\begin{tabular}{lllll}
\hline Parameters & Unit & Min. Conc. & Max. Conc. & Average Conc. \\
\hline COD & $\mathrm{mg} / \mathrm{l}$ & 112.3 & 385.4 & 202.02 \\
$\mathbf{N H}_{\mathbf{4}}{ }^{+}-\mathbf{N}$ & $\mathrm{mg} / \mathrm{l}$ & 12.9 & 38.4 & 22.77 \\
$\mathbf{T N}$ & $\mathrm{mg} / \mathrm{l}$ & 18.6 & 43.8 & 31.59 \\
$\mathbf{T P}$ & $\mathrm{mg} / \mathrm{l}$ & 0.69 & 3.26 & 2.02 \\
\hline
\end{tabular}

\section{Taguchi Orthogonal Array (TOA) Method}

The TOA L $\mathrm{L}_{9}\left(3^{4}\right)$ was applied to define the optimum conditions regarding the selected factors to achieve high COD removal efficiency by using the UAF anaerobic reactor. The experimental design 
involved four factors with three levels for each one, and the selected factors are $\mathrm{pH}$, HRT, temperature, OLR. Table 2 illustrated the factors and their levels, which selected in this study. Based on the TOA $\left(\mathrm{L}_{9}\right)$ layout, nine experiments were conducted with the different combinations of the levels, as shown in Table 2. Each level group of the experiments was performed in triplicate.

Table 2 Controlled variables and their levels

\begin{tabular}{lllll}
\hline $\begin{array}{l}\text { Control va- } \\
\text { riables (Factors) }\end{array}$ & Unit & $\begin{array}{l}\text { Level } \\
\mathbf{1}\end{array}$ & $\begin{array}{l}\text { Level } \\
\mathbf{2}\end{array}$ & $\begin{array}{c}\text { Level } \\
\mathbf{3}\end{array}$ \\
\hline pH & - & 6.5 & 7 & 7.5 \\
Temperature & ${ }^{\circ} \mathrm{C}$ & 15 & 20 & 25 \\
$\begin{array}{l}\text { Hydraulic re- } \\
\text { tention time } \\
\text { (HRT) }\end{array}$ & hours & 18 & 24 & 36 \\
$\begin{array}{l}\text { Organic loading } \\
\text { Rate (OLR) }\end{array}$ & $\begin{array}{l}\text { Kg. } \\
\text { COD/ } \\
\mathrm{m}^{3} \text {.day }\end{array}$ & 0.166 & 0.25 & 0.333 \\
& & & \\
\hline
\end{tabular}

\section{Analytical Methods}

The UAF reactor performance efficiency based on organic matter removal was evaluated. The influent and effluent COD concentrations were measured according to the standard methods ${ }^{[7]}$. The COD removal in UAF reactor indicates to a difference between the influent and effluent of COD concentrations; hence the COD removal efficiency ratio was calculated and expressed by using equation 1:

$$
\mathrm{COD} \text { removal } \%=\frac{\mathrm{COD}_{\text {inlet }} ? \mathrm{COD}}{\mathrm{COD}_{\text {inlet }}} \times 100
$$

Where the $\mathrm{COD}_{\text {inlet }}$ and $\mathrm{COD}_{\text {out }}$ are the influent and the effluent COD concentrations.

Taguchi method analyzed the experimental results by using signal to noise ratios ( $/ \mathrm{N})$ and analysis of variance (ANOVA). The main target of these experiments is to maximize the COD removal efficiency to improve the quality of treated wastewater through the UAF process. Therefore, the definition of S/N as "larger is better" of quality characteristic is selected, and can be expressed according to the equation.

In addition, the percentage contribution (PC \%) of each factor on the COD removal process was obtained by using equation (2) as below.

$$
\begin{aligned}
\mathrm{PC}^{\prime}= & =\frac{\mathrm{SS}^{\prime}}{\mathrm{SS}_{\text {Total }}} \times 100 \\
\mathrm{SS}^{\prime} & =\mathrm{SS}-\mathrm{SS}_{\text {error }}
\end{aligned}
$$

Where: $\mathrm{SS}^{\prime}$ is referred to the pure sum of square; $\mathrm{SS}$ is the individual sum of squares; $\mathrm{SS}_{\text {error }}$ is the sum of square error; $\mathrm{SS}_{\text {Total }}$ is the total sum of squares of factors.

Furthermore, the Design-Expert ${ }^{\circledR}$ software was used for the generation and evaluation of our experiments design model. All experimental results were analyzed using this software to perform statically model and analysis of variances (ANOVA). The data were expressed as the mean value and the level of significance was taken at p-value of 0.01. Furthermore, the confirmation tests were conducted to compare the experimental results with predicted results.

\section{RESULTS AND DISCUSSIONS}

\section{Optimization of COD removal via UAF reactor}

The $\mathrm{S} / \mathrm{N}$ ratio was determined, and ANOVA analysis was performed to analyze the experimental results. Moreover, these ratios serve as the objective functions for optimization, and presented further 
help in data analysis and prediction of the optimum results. Furthermore, ANOVA is utilized to identify the optimum combination factors for realizing the process target as more accurately by investigating the relative importance of these factors. Experimental results are recorded as the COD removal efficiency and then the corresponding $\mathrm{S} / \mathrm{N}$ ratios were calculated according to equation (2). The effect of the main factors on the average $\mathrm{S} / \mathrm{N}$ ratio was illustrated in Fig 2 . The level of the factors with highest average $\mathrm{S} / \mathrm{N}$ ratio indicates to better performance of the process and gives the best combination level. Therefore, the optimum combination levels of these factors based on the $\mathrm{S} / \mathrm{N}$ ratios analysis and the response function were $\mathrm{A}_{2} \mathrm{~B}_{3} \mathrm{C}_{3} \mathrm{D}_{1}$, as shown in Fig. 2. It is evident that the HRT and temperature factors have significant influence on COD removal efficiency when adjusted on its highest levels.

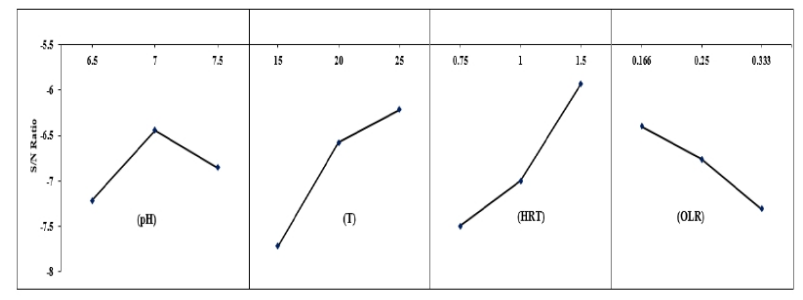

Fig. 2 Main factors effect on $\mathrm{S} / \mathrm{N}$ ratios ( $\mathrm{S} / \mathrm{N}$ ratio defined as larger is better)

On the other hand, the analysis of variance (ANOVA) of multi factors was conducted, which were illustrated in Table 3. Furthermore, all the factors in this model were statically significant different at ( $\mathrm{P}<0.01$ ). Based on ANOVA analysis, the HRT and temperature factors had a highly significant effect, according to their mean sum of a square. The last column in Table 3 presented the percentage of contribution (PC \%) of all factors on the process performance.

Table 3 ANOVA analysis and the factors contribution percentage on the process.

\begin{tabular}{|c|c|c|c|c|c|c|}
\hline Factor & $\begin{array}{l}\text { Sum of square } \\
(\mathrm{SS})\end{array}$ & $\begin{array}{l}\text { Degree of } \\
\text { freedom } \\
\text { (DF) }\end{array}$ & $\begin{array}{l}\text { Mean sum } \\
\text { of square } \\
(\mathrm{MS})\end{array}$ & F-value & $\begin{array}{l}\text { Pure sum } \\
\text { of } \\
\text { square(SS') }\end{array}$ & $\mathrm{PC} \%$ \\
\hline Model & 0.085 & 8 & 0.011 & 237.6 & & Significant* \\
\hline A & 0.009 & 2 & 0.0045 & 95.4 & 0.008 & 9.18 \\
\hline B & 0.029 & 2 & 0.015 & 328.9 & 0.029 & 33.78 \\
\hline $\mathrm{C}$ & 0.035 & 2 & 0.017 & 387.5 & 0.034 & 39.92 \\
\hline $\mathrm{D}$ & 0.012 & 2 & 0.006 & 138.8 & 0.012 & 13.75 \\
\hline Error & $7.14 \times 10^{-4}$ & 16 & $4.46 \times 10-5$ & & 0.0029 & 3.37 \\
\hline Total & 0.085 & 26 & & & 0.085 & 100.00 \\
\hline
\end{tabular}

Pure Total $\quad 0.082$

[*This sign indicates that the model and all factors were statically significant, and the model showed $\mathrm{R}^{2}$ of 0.9917 and the Adj $\mathrm{R}^{2}$ is 0.9875$]$.

\section{Performance efficiency of the UAF reactor for long term operation}

The UAF reactor was ran continuously three months with real domestic wastewater to evaluate the reactor performance for long time operation. The raw domestic wastewater was taken from the main manhole in southeast university, Wuxi campus. In addition, the UAF reactor was operated in four phases at different operation conditions that considered in the previous of optimization study. The results illustrated in Figs. 3, 4 and Table 4 showed the effect of the HRT, OLR, and temperature on 
the COD removal efficiency in UAF reactor. In the first phase of operation, the reactor ran with 36 hrs of HRT which resultant the average OLR was $0.142 \mathrm{~kg} \mathrm{COD} / \mathrm{m}^{3}$.day. The average concentration of the influent COD during this phase was $213.3 \mathrm{mg} / \mathrm{l}$ and the average COD removal efficiency achieved was $56.5 \%$ with the final average effluent concentration of $89.1 \mathrm{mg} / \mathrm{l}$. Moreover, the decreasing of HRT in the following operation phases to 24, 18 and $12 \mathrm{hrs}$ with the gradually increasing of the OLR to $0.2,0.28$ and $0.32 \mathrm{~kg}$. COD $/ \mathrm{m}^{3}$.day, respectively leads to decrease of the COD removal efficiency from $53.1 \%$ to $45.9 \%$ and then $39.9 \%$. These results demonstrated that the COD removal efficiency increased with an increase the HRT, Fig. 4. shown this result. Moreover, the results also indicated that the temperature has a significant effect on the COD removal efficiency, where the increase in temperature usually resulted into improved removal efficiency (see Table 4). The changes of COD removal efficiencies during the whole experimental operations are illustrated in Fig. 5.3. The results revealed that the average COD removal efficiency during the entire experiments was $50.8 \%$ with mean effluent concentration of $94.5 \mathrm{mg} / \mathrm{l}$. Yu and et al. studied a hybrid UASB$\mathrm{AF}$ for treating pre-settled municipal wastewater at the ambient temperatures $\left(18 \sim 28{ }^{\circ} \mathrm{C}\right)$ and found that the COD removal decreased from $67.8 \%$ to $52.3 \%$ when the HRT decreased from 4 to $2 \mathrm{hrs}{ }^{[8]}$.

Table 4 Average of influent and effluent COD concentrations and removal efficiencies through UAF reactor at the different operation conditions.

\begin{tabular}{llllll}
\hline $\begin{array}{l}\text { HRT } \\
(\mathrm{hrs})\end{array}$ & $\begin{array}{l}\text { Temp. } \\
\left({ }^{\circ} \mathrm{C}\right)\end{array}$ & $\begin{array}{l}\text { OLR } \\
(\text { Kg. COD } \\
\left./ \mathrm{m}^{3} . \text { day }\right)\end{array}$ & $\begin{array}{l}\text { COD. inf } \\
(\mathrm{mg} / \mathrm{l})\end{array}$ & $\begin{array}{l}\text { COD. eff } \\
(\mathrm{mg} / \mathrm{l})\end{array}$ & $\begin{array}{l}\text { COD Remov- } \\
\text { al \% }\end{array}$ \\
\hline 36 & 25 & 0.142 & 213.29 & 89.11 & 56.5 \\
24 & 20 & 0.20 & 200.31 & 92.06 & 53.1 \\
18 & 15 & 0.28 & 211.9 & 110.89 & 45.9 \\
12 & 15 & 0.32 & 156.64 & 93.76 & 39.9 \\
\hline
\end{tabular}

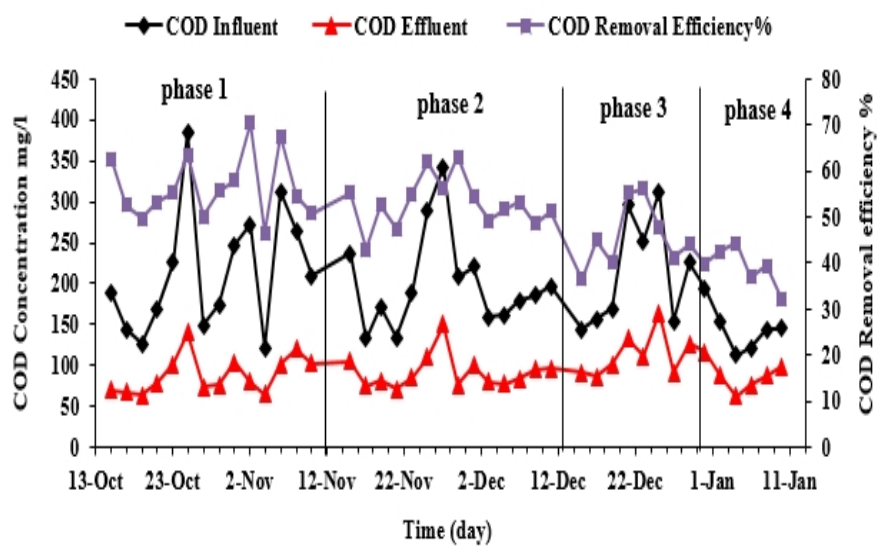

Fig. 3 Performance efficiency of UAF reactor based on the COD removal (Laboratory scale)

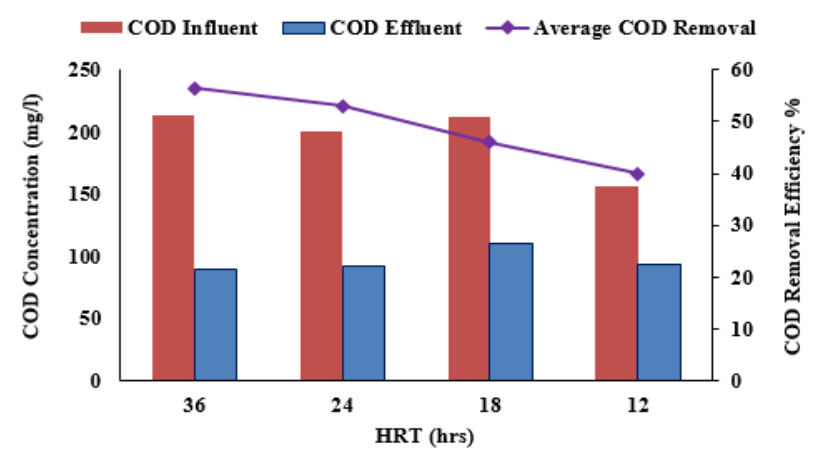

Fig 4 Effect of HRT on the COD removal efficiency in anaerobic reactor (Laboratory- scale) 


\section{CONCLUSIONS}

The laboratory scale of UAF reactors were used to evaluate and optimize their treatment performance. The Taguchi orthogonal array was applied successfully to design the experiments, build model and determine the optimum conditions for improving the removal of COD in UAF reactor. According to results of the $\mathrm{S} / \mathrm{N}$ ratio and ANOVA analysis, demonstrated that the optimum combination of factors with levels for achieving a maximum COD removal was A2B3C3D1, which corresponding to $\mathrm{pH} 7$, temperature $25^{\circ} \mathrm{C}$, HRT $36 \mathrm{hrs}$ and OLR $0.166 \mathrm{~kg} \mathrm{COD} / \mathrm{m}^{3}$. day.

Additionally, ANOVA analysis was shown statically significant for all factors and the results demonstrated the percentage contribution of the HRT, temperature, OLR and $\mathrm{pH}$ factors on the COD removal process were $39.92 \%, 33.78 \%, 13.37 \%$ and $9.18 \%$, respectively. Under optimization parameters which obtained from Taguchi method, the performance of UAF reactor for long term operation was evaluated and the results revealed that the average COD removal during experimental operations ranged between $46.5 \% \sim 70.3 \%$ with the total average COD removal of $56.5 \%$ and the average final COD removal is $89.1 \mathrm{mg} / \mathrm{l}$. Moreover, the results of COD removal obtained during operation laboratory-scale of the UAF reactor is better than the results of a previous study of UAF reactor at the temperature ranged of $15 \sim 25{ }^{\circ} \mathrm{C}$. This is indicated that the type of media used in lab scale UAF reactor provided a good biomass growth and attachment anaerobic bacteria.

\section{ACKNOWLEDGMENTS}

This research has been supported by major science and technology program for water pollution control and treatment (2012ZX07101-005) and national natural science foundation of China (51078074).

\section{REFERENCES}

[1] U. B. Deshannavar, B. R. K, and N. M. Naik. High rate digestion of dairy industry effluent by upflow anaerobic fixed-bed reactor [J]. Journal of Chemical and Pharmaceutical Research, 4(6): 2895-2899, 2012.

[2] H. Gannoun, H. Bouallagui, A. Okbi, S. Sayadi, and M. Hamdi. Mesophilic and thermophilic anaerobic digestion of biologically pretreated abattoir wastewaters in an upflow anaerobic filter [J]. $J$ Hazard Mater, 170(1): 263-71, Oct 152009.

[3] A. López-López, M. G. Albarran-Rivas, L. Hernandez-Mena, and E. Leon-Becerril. An assessment of an anaerobic filter packed with a low-cost material for treating domestic wastewater [J]. Environ Technol, 34(9-12): 1151-9, May-Jun 2013.

[4] G. Lettinga. Anaerobic digestion and wastewater treatment systems [J]. Antonie van Leeuwenhoek $67 \quad$ (1): 3 - 281995.

[5] T. Yilmaz. Modeling the performance of upflow anaerobic filter (UAF) reactors treating papermill wastewater using neural networks [J]. Scientific Research and Essays, 8(38): 1896-1905, 2013.

[6] L. Seghezzo. Anaerobic Treatment of domestic wastewater in subtropical regions [D]. Ph.D. thesis Thesis., Wageningen University, para Adriana, Natalia y Mateo, 2004.

[7] S. E. P. A. Chinese. Water and Wastewater Monitoring Methods [B], fourth ed. Beijing, China.: Chinese Environmental Science Publishing House, 2002.

[8] H. Yu and G. K. Anderson. Performance of a combined anaerobic reactor for municipal wastewater treatment at ambient temperature [J]. Resources, Conservation and Recycling, 17(4): 259-271, 10// 1996. 